\title{
Identification of Cardiovascular Related Changes by Regular Routine Medical Checkups in Aged People
}

M.V.Sailaja*1, V.S.Bhagyalakshmi ${ }^{2}$, Vijitha ${ }^{3}$,

${ }^{* 1}$ Associate Professor, Department of Physiology, Viswabharati M edical College, Kurnool, Andhra Pradesh, India.

${ }^{2}$ Associate Professor, Department of Physiology, SV M edical College, Tirupati, Andhra Pradesh, India.

${ }^{3}$ Assistant Professor, Department of Physiology, ACSR Govt. Medical College Nellore, Andhra Pradesh, India.

\section{ABSTRACT}

Due to the age related diseases causes the cardiovascular risk in elderly people when compared to normal people. $50 \%$ of all heart failure diagnoses and $90 \%$ of all heart failure deaths occurring in the segment of the population over age 70, heart failure is largely a disease of the elderly. The detection of the cardiovascular related Changes can be identified during regular routine medical checkups by lipid profile, the flow velocities of internal carotid artery \& vertebral artery by Doppler, and echo cardiography, among normal adults and aged people and compared with normal peoples. The heart rate of the subjects and controls is found to be nonsignificant. The SBP and DBP of the subjects is found to be greater in ageing when compared with normal men due to changes in big arteries include stiffness of elastic tissue with much thicker and less flexible walls. This causes the increase force of ventricular contraction and SBP. The increase in large vessel stiffness plays a central patho physiological role in hypertension in older individuals. The lipid profile of the subjects is greater than the controls due to increase in plasma or serum lipid levels. This indicates the risk factor atherosclerosis in ageing. This is one of the predisposing factors for heart attacks and cerebral strokes. Changes can be identified during regular routine medical checkups and the changes can be minimized by prescribing suitable diet, rest, minimal exercises.

KEY WORDS: Cardiovascular Rick, Lipid Profile, Doppler, Echo Cardiography.

Address for correspondence: Dr. M.V.Sailaja, Associate Professor, Department of Physiology, Viswabharati Medical College, Kurnool, Andhra Pradesh, India. E-Mail: kvsailaja74@gmail.com

\begin{tabular}{|c|c|c|}
\hline \multicolumn{3}{|c|}{ Online Access and Article Informtaion } \\
\hline \multirow{2}{*}{ 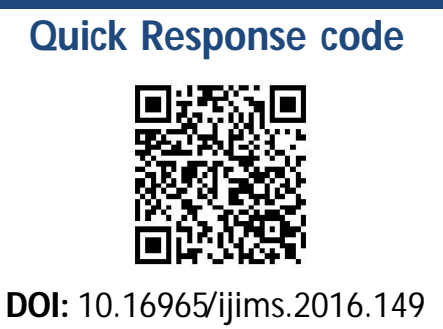 } & \multicolumn{2}{|c|}{$\begin{array}{l}\text { International Journal of Integrative Medical Sciences } \\
\qquad \text { www.imedsciences.com }\end{array}$} \\
\hline & $\begin{array}{l}\text { Received: 12-09-2016 } \\
\text { Reviewed: 12-09-2016 }\end{array}$ & $\begin{array}{l}\text { Accepted: 26-09-2016 } \\
\text { Published: 06-10-2016 }\end{array}$ \\
\hline Source of Funding: Self & & est: None \\
\hline
\end{tabular}

\section{BACKGROUND}

Age is a threshold for manifestation of the disease and leads to cause heart failure (HF), as the populations of most developed countries continue to become older, on average, the importance of aging as a risk factor for all cardiovascular disease increases in kind. Aging represents a convergence of declining cardio protective systems and increasing disease processes that is fertile ground for the development of heart failure. With $50 \%$ of all heart failure diagnoses and $90 \%$ of all heart failure deaths occurring in the segment of the population over age 70 , heart failure is largely a disease of the elderly [1].

Ageing is a normal physiological process characterized by alterations in cell and tissue 
structures associated with a reduction in functional capacity-physical, sexual, mental. There is a graded and progressive reduction in the homeostatic reserve function of organs and systems as age advances and is referred to as Homeostenosis [2]. Many theories of ageing have been proposed to explain certain manifestations of ageing process. In United States the proportion of people aged 64 and more is projected to increase from $12.54 \%$ ( 35 million) of population in 2000 and $19.6 \%$ (71 million) in 2030 . Almost $50 \%$ of aged people have income less than liable for tax and indicates poverty. M ore than $80 \%$ of all deaths due to cardiovascular diseases occur in elderly people above 60 years. Coronary artery disease is also common in ageing and is likely to involve multiple vessels and mainly left coronary artery. Though the physiological changes with ageing do not appear at specific age, WHO uses 60 years of age to define elderly [3].

Age based changes may be observed at cellular as well as at gross level. The cells from senescent cultures show a decline in DNA repair activity. The connective tissues throughout the body show an increase in the rate of hydrolysis of elastin. The systemic age related changes are broadly in the nature of reduced maximum capacity, reduced tolerance, impaired peak performance or diminished reserve. Aging is associated with impaired endothelial dependent vascular relaxation and that this is selective, with no age related change in endothelial independent vascular relaxation or angiotensin2 mediated vascular contraction $[1,4]$.

\begin{tabular}{|c|c|c|c|}
\hline \multirow{7}{*}{$\begin{array}{l}\text { Fig. 1: Showing the } \\
\text { various changes in the } \\
\text { organs in relation to age } \\
\text { related changes and } \\
\text { cardiovascular } \\
\text { disease. }\end{array}$} & ORGAN & AGE ASSOCIATED CHANGES & CARDIOVASCULAR DISEASE \\
\hline & VASCULATURE & $\begin{array}{c}\text { Increased initial thickness } \\
\text { Arterial stiffening } \\
\text { Pulse pressure } \\
\text { Pulse wave velocity } \\
\text { Early central wave reflections } \\
\text { Endothelium mediated } \\
\text { vasodilatation }\end{array}$ & $\begin{array}{l}\text { Systolic by pretension } \\
\text { Coronary artery obstruction } \\
\text { Peripheral artery obstruction } \\
\text { Cortaid artery obstruction }\end{array}$ \\
\hline & ATRIA & $\begin{array}{l}\text { Left atrial size } \\
\text { Atrial premature complexes }\end{array}$ & Atrial fibrilation \\
\hline & SINUS NODE & Maximal HR & $\begin{array}{l}\text { Sinus node dysfunction } \\
\text { Sinus syndrome }\end{array}$ \\
\hline & $\begin{array}{c}\text { ATRIOVENTRICULAR } \\
\text { NODE }\end{array}$ & Conduction time & Type III black, 3 block \\
\hline & VALVES & Sclerosis, Clarification & Stenosis, Regurgitation \\
\hline & VENTRICLE & $\begin{array}{c}\text { LV wall tension } \\
\text { Prolonged myocardial contraction } \\
\text { Diastolic filling rate M ax Co } \\
\text { Right bundle branch block } \\
\text { Ventricular premature complexes }\end{array}$ & $\begin{array}{c}\text { LV hypertrophy } \\
\text { HF } \\
\text { Ventricular taxycardia, } \\
\text { Fibrillations }\end{array}$ \\
\hline
\end{tabular}

Cardiovascular ageing in humans include, vasodilatation in response to beta adrenergic progressive increase in systolic blood pressure, pulse pressure, pulse wave velocity and left ventricular mass and increased incidence of coronary artery disease and atrial fibrillation. Reproducible age related decreases are seen in rates of early left ventricular diastolic filling, maximal heart rates, maximal cardiac output, maximal aerobic capacity or maximal oxygen consumption ( $\mathrm{vo}_{2} \mathrm{max}$ ), exercise induced augmentation of ejection fraction, reflex responses of heart rate, heart rate variability, stimuli or endothelium mediated vasodilator compounds. Cellular, enzymatic and molecular alterations in the arterial vessel wall include migration of activated vascular smooth muscle cells into the intima. Endothelial cell production of Nitric oxide (NO) decreases with age. Vascular responses to beta adrenergic agonists and alpha adrenergic blockade are also reduced with ageing. Consistent changes in the autonomic system accompany ageing and influence cardiovascular function [1]. 
The beta adrenergic system, age related changes include decreased receptor numbers, altered G-protein coupling and altered G-protein mediated signal transduction. Age related decrease in alpha adrenergic platelet receptors and decreased alpha adrenergic mediated arterial vasoreactivity of fore arm blood vessels occur but alpha-adrenergic mediated changes in human hand veins appear to be preserved. The age related autonomic changes lead to decreased baroreflex function and responses to physiological stressors with increased sensitivity to parasympathetic stimulation of the central nervous system. Age related changes are also seen in the intravascular environment. Increase in fibrinogen, coagulation factors V, VIII, IX and other coagulation proteins are seen without countering increase in anticoagulant factors. Platelet phospholipids content is altered and increased with increased binding of PDGF to the arterial wall in older individuals. Increased levels of PAI-1 are seen with ageing, especially during stress resulting in impaired fibrinolysis .circulating prothrombotic inflammatory cytokines especially IL- 6 also increased in age and may play a role in the pathogenesis of acute coronary syndromes [1]. Adipose cells sassociated with obesity are also sources of PAI-1 and inflammatory cytokines. All these changes also potentiate development of atherosclerosis. Changes can be identified during regular routine medical checkups and the changes can be minimized by prescribing suitable diet, rest, minimal exercises [1]. Aim of the study was evaluation of cardiovascular function in aged people by lipid profile, the flow velocities of internal carotid artery $\&$ vertebral artery by Doppler, and echo cardiography, among normal adults and aged people and compared with normal peoples.

\section{MATERIALS AND METHODS}

Case control study was conducted in the RIMS, Kadapa, after Permission taken from medical ethics committee of the Institute. Total 40 voluntaries was participated in the study those who re requited after examined clinically by physician. They are divided into two groups: 20 normal healthy individuals aged between 40 to 49 years are selected as controls, and 20 Males aged 50 to 70 years with hyper tension are taken. Smokers, alcoholic subjects are also included. Patients with Diabetes mellitus, arteriovenous fistula, known case of coronary arterial disease, congenital heart disease were excluded from the study. Blood pressure was recorded by sphygmomanometer. The recordings were recorded at 10am for three days. Average of the readings was calculated to confirm hypertension. $3 \mathrm{ml}$ of venous blood was collected and centrifuged at 3000 RPM for 10 minutes for collection of serum. Serum was used for assaying of biochemical parameters like serum cholesterol, Triglycerides and HDL cholesterol. These are estimated using enzymatic kits on visible spectrophotometer.

Echocardiography is easily performed, noninvasive, safe, reproducible and accurate. This technique uses the ultra sound waves reflected at blood and tissues interfaces to study the heart and its functions. A Piezo-electric crystal transducer which emits ultra-sonic waves at a frequency of $2 \mathrm{M} \mathrm{HZ}$ is placed on the body surface. The reflected waves from the various parts of the heart are detected by the transducer which acts as a receiver. It gives the information about thickness of the walls, chambers and septum, chamber diameter and their changes, valve thickness and movements. The volume and velocity of blood flow through the valves can also be measured if combined with Doppler techniques. The information provide has considerably facilitate the diagnosis of cardiac disorders. Echocardiography uses the ultra sound waves reflected at blood and tissue interfaces to study the heart and its functions. Echo was done by using IE-33 machine 2D measurements [5].

An echocardiograph examination begins with transthoracic two dimensional (2D) scanning from four standard transducer positions the parasternal, apical, sub costal and suprasternal windows. The parasternal and apical views usually are obtained with the patient in the left lateral decubitus position and the sub costal and supra sternal notch views with the patient in the supine position. An examiner may sit at the left or right side of the patient and can scan with right or left handed respectively. From each transducer position multiple tomographic 
Fig. 2: Showing the eco graphic finds of the Internal Carotid artery.

Fig. 3: Showing the Eco graphic findings of the vertebral artery.
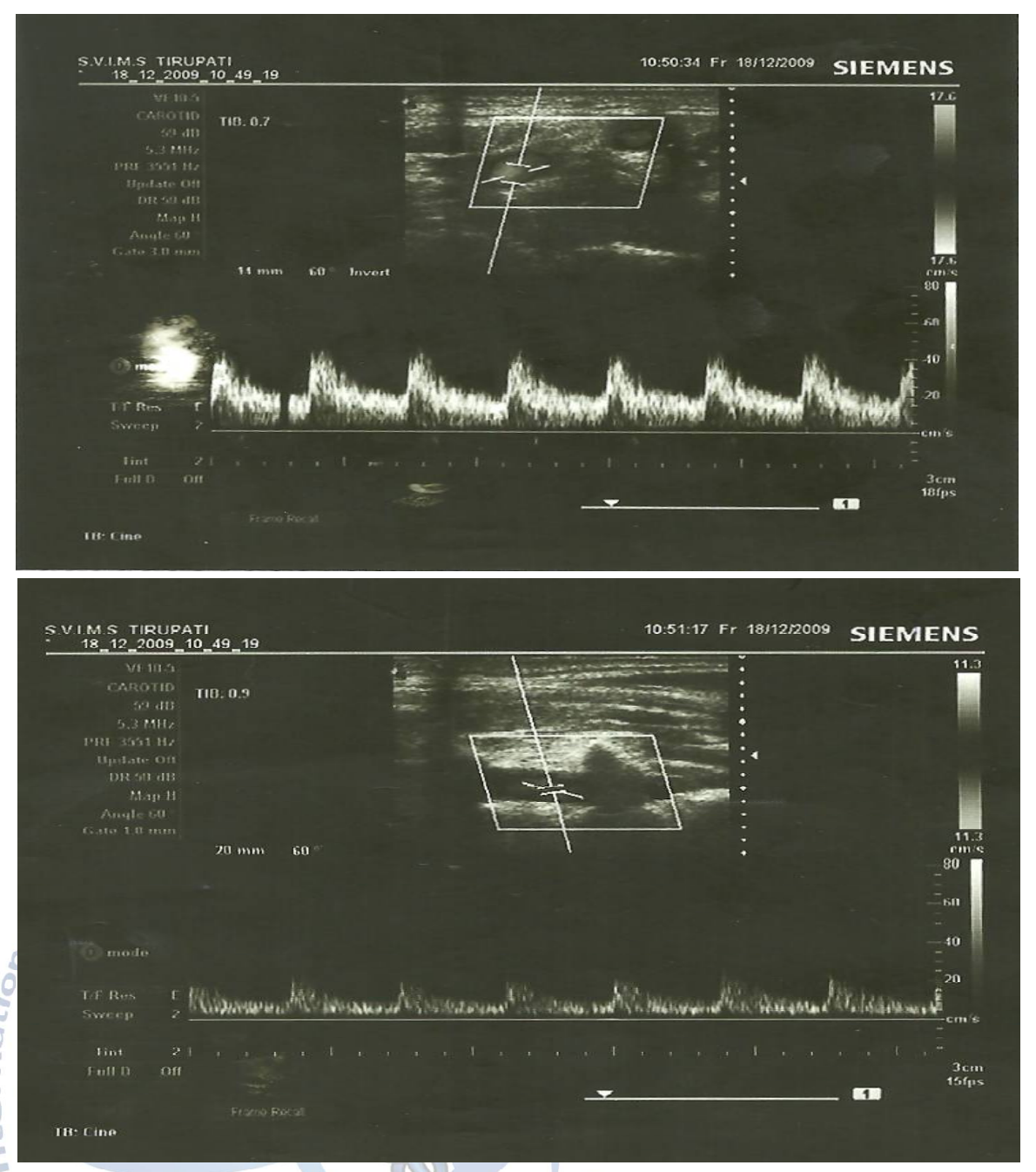

images in the heart relative to its long and short axes are obtained by manually rotating and angulating the transducer hence a multilane examination is performed. The long axis view represents a sagittal or coronal section of the heart bisecting the heart from the base to the apex. The short axis view perpendicular to long axis view and is equivalent to sectioning the heart like a loaf of bread. Real time 2D echocardiography provides high resolution images of cardiac structures and their movements so that detailed anatomic and functional information about the heart can be obtained. Therefore 2D echocardiography is the basis of morphologic and functional assessments of the heart. Quantitative measurements of cardiac dimensions area and volume are derived from $2 D$ images or $2 D$ derived $M$ mode. 2D echocardiography provides the frame wok for Doppler and colour flow image [6].Doppler is a non-invasive procedure, easy to perform and not time consuming and is used widely in clinical practice. This technique of measurement has been validated in earlier studies by Celermajer etal. Primarily, evidence suggest that non invasive assessment of carotid artery and vertebral artery flow mediated vasodilatation will become an important tool in helping to define important and complex interactions between cardiac risk factors, endothelial dysfunction and atherosclerosis. External ultrasound imaging provides a detailed picture of the anatomy of the arterial wall. Small changes in the vessel diameter can be detected by means of a high resolution linear array transducer [7].

\section{RESULTS}

Table 1: Comparison of Age of control and subjects.

\begin{tabular}{|c|c|c|c|c|c|c|}
\hline & \multicolumn{2}{|c|}{ CONTROLS } & \multicolumn{2}{|c|}{ SUBJECTS } & & \\
\hline & MEAN & SD & MEAN & SD & T-VALUE & P.VALUE \\
\hline AGE (YEAR) & 45.4 & 3.16 & 59.1 & 7.44 & -5.823 & $0.000 ; 5$ \\
\hline
\end{tabular}

The mean age group of controls $45.4 \pm 3.1$ years is less than the subject's $59.1 \pm 7.44$ years and the " $P$ " value is statistically significant. 
Table 2: Comparison of BMI values of controls and subjects.

\begin{tabular}{|c|c|c|c|c|c|c|}
\hline & \multicolumn{2}{|c|}{ CONTROLS } & \multicolumn{2}{c|}{ SUBBECTS } & \multicolumn{2}{c|}{} \\
\cline { 2 - 7 } & MEAN & SD & MEAN & SD & T-VALUE & P.VALUE \\
\hline BMI $\left(\mathrm{Kg} / \mathrm{m}^{2}\right)$ & 24.6 & 1.62 & 24.03 & 2.64 & 0.57 & $0.583 ; 5$ \\
\hline
\end{tabular}

The mean BMI of controls is $24.6 \pm 1.6 \mathrm{~kg} / \mathrm{m}^{2}$ is higher than subjects $24.03 \pm 2.64 \mathrm{~kg} / \mathrm{m}^{2}$ and the "p-value is statistically significant.

Table 3: Comparision of HR values of controls and subjects.

\begin{tabular}{|c|c|c|c|c|c|c|}
\hline & \multicolumn{2}{|c|}{ CONTROLS } & \multicolumn{2}{c|}{ SUBJECTS } & & \\
\hline & MEAN & SD & MEAN & SD & T-VALUE & P-VALUE \\
\hline HR (Beats/ min) & 77.5 & 5.79 & 78.5 & 11.24 & -0.212 & 0.837 ;NS \\
\hline
\end{tabular}

The mean values of heart rate of controls 77.5/ $\min \pm 5.79$ is less than the subjects $78.5 / \mathrm{min} \pm$ 11.2 and " $P$ " value is statistically non-significant.

Table 4: Comparison of SBP AND DBP values of controls and subjects.

\begin{tabular}{|l|c|c|c|c|c|c|}
\hline & \multicolumn{2}{|c|}{ CONTROLS } & \multicolumn{2}{c|}{ SUBJEETS } & & \\
\cline { 2 - 7 } & MEAN & SD & MEAN & SD & T-VALUE & P.VALUE \\
\hline SBP $(\mathrm{mm}$ of Hg) & 115 & 7.07 & 148 & 19.8 & -5.361 & $0.000 ; 5$ \\
\hline DBP $(\mathrm{mm}$ of $\mathrm{Hg})$ & 84 & 8.43 & 94 & 5.16 & -2.535 & $0.032 ; 5$ \\
\hline
\end{tabular}

The mean value of SBP of controls $115.0 \mathrm{~mm}$ of $\mathrm{Hg} \pm 7.07$ is less than the subjects $148.0 \mathrm{~mm}$ of $\mathrm{Hg} \pm 19.8$ and " $P$ " value is statistically significant. The mean value of DBP of controls $84.0 \mathrm{~mm}$ of $\mathrm{Hg} \pm 8.43$ is less than the subjects $94.0 \mathrm{~mm}$ of $\mathrm{Hg} \pm 5.16$ and " $\mathrm{P}$ " value is statistically significant.

Table 5: Comparison of serum cholesterol, serum triglyceride, serum HDL among controls and subjects.

\begin{tabular}{|c|c|c|c|c|c|c|}
\hline & \multicolumn{2}{|c|}{ CONTROLS } & \multicolumn{2}{|c|}{ SUB|EETS } & \multirow[b]{2}{*}{ T.VALWE } & \multirow[b]{2}{*}{ P.VALLE } \\
\hline & MEAN & SD & MEAN & SD & & \\
\hline $\begin{array}{l}\text { SERUM CHOLETEROL } \\
\text { (mo/dll) }\end{array}$ & 162.1 & 21.19 & 21.4 & 25.5 & -3.722 & $0.001 ; 5$ \\
\hline $\begin{array}{l}\text { SERUM TRIGLYYERIDES } \\
(\mathrm{mg} / \mathrm{dl})\end{array}$ & 155.3 & 39.01 & 258.1 & 32.28 & -7.817 & $0.000 ; 5$ \\
\hline $\begin{array}{l}\text { SERUM HDL } \\
\text { (mg/dll) }\end{array}$ & 52 & 9.96 & 93.4 & 15.33 & -6.524 & $0.000 ; 5$ \\
\hline
\end{tabular}

The mean value of serum cholesterol of controls $162.1 \mathrm{mg} / \mathrm{dl} \pm 21.19$ is less than subjects $212.4 \mathrm{mg} / \mathrm{dl}+25.5$ and "P" value is statistically significant. The mean value of serum triglyc eride of controls $155.3 \mathrm{mg} / \mathrm{dl} \pm 39.01$ is less than subjects $258.10 \mathrm{mg} / \mathrm{dl} \pm 32.28$ and " $P$ " value is statistically significant. The mean value of serum HDL of controls $52.0 \mathrm{mg} / \mathrm{dl} \pm 9.96$ is less than subjects $93.4 \mathrm{mg} / \mathrm{dl} \pm \mathbf{1 5 . 3 3}$ serum HDL and "P" value is statistically significant.

Int J Intg M ed Sci 2016;3(9):412-18. ISSN 2394 - 4137
Table 6: Comparison of echocardiography of ejection fraction and inter ventricular septal diameter of controls and subjects.

\begin{tabular}{|c|c|c|c|c|c|c|}
\hline \multirow{2}{*}{} & \multicolumn{2}{|c|}{ CONTROLS } & \multicolumn{2}{c|}{ SUBJECTS } & & \\
\cline { 2 - 7 } & MEAN & SD & MEAN & SD & T-VALUE & P.VALUE \\
\hline EF 1\% & 66.1 & 4.22 & 42.5 & 10.14 & 6.223 & $0.000 ; 5$ \\
\hline IVSD-S $(\mathrm{mm})$ & 9.2 & 0.91 & 8.4 & 1.5 & 1.177 & $0.269: \mathrm{NS}$ \\
\hline IVSD-D (mm) & 13 & 1.88 & 11.2 & 3.29 & 1.227 & $0.251 ;$ NS \\
\hline
\end{tabular}

The mean value of ejection fraction of controls $66.10 \% \pm 4.22$ is higher than subjects $42.50 \% \pm$ 10.14 and " $P$ " value is statistically significant. The mean value of inter ventricular septal diameter of controls IVSD diameter is $9.20 \mathrm{~mm} \pm$ 0.91 is higher than subjects $8.40 \mathrm{~mm} \pm 1.50$ and " $P$ " value is statistically non-significant. The mean value of inter ventricular septal diameter of controls is $13.0 \mathrm{~mm} \pm 1.88$ is higher than subjects $11.20 \mathrm{~mm} \pm 3.29$ and " $P$ " value is statistically non-significant.

Table 7: Comparison of internal carotid artery flow velocity of subjects before and after treatment: peak systolic velocity/ end diastolic velocity.

\begin{tabular}{|c|c|c|c|c|c|c|c|}
\hline \multirow{2}{*}{ FLOW VELOCITY } & & \multicolumn{3}{|c|}{$\begin{array}{c}\text { SUBBECTS BEFORE } \\
\text { TREATMENT }\end{array}$} & \multicolumn{2}{|c|}{$\begin{array}{c}\text { SUBJECTS AFTER } \\
\text { TREATMENT }\end{array}$} & \multicolumn{2}{|c|}{} \\
\cline { 2 - 8 } & & MEAN & SD & MEAN & SD & T-VALUE & P.VALUE \\
\hline $\begin{array}{c}\text { RIGHT INTERNAL } \\
\text { CAROTID ARTERY } \\
\text { (Cm/SeC) }\end{array}$ & PSV & 51.4 & 9.8 & 78.2 & 14.34 & 4.87 & $\varangle .001 ; 5$ \\
\cline { 2 - 8 } & EDV & 18.6 & 5.62 & 30.8 & 9.73 & 3.43 & $0.002 ; 5$ \\
\hline $\begin{array}{c}\text { LEFT INTERNAL } \\
\text { CAROTID ARTERY } \\
\text { (Cm/Sec) }\end{array}$ & PSV & 41.5 & 7.31 & 66.3 & 31.7 & 2.41 & $0.02 ; 5$ \\
\hline
\end{tabular}

The mean value for flow velocity of internal carotid artery right in subjects before treatment in $\mathrm{cm}$ is $51.4 \pm 9.08$ is less than in subjects after treatment in $\mathrm{cm}$ is $78.2 \pm 14.34$ and " $\mathrm{P}$ " value is statistically significant. The mean value for flow velocity of internal carotid artery left in subject before treatment in $\mathrm{cm}$ is $41.5 \pm 7.31$ is less than in subjects after treatment in $\mathrm{cm}$ is $66.3 \pm 31.7$ and " $P$ " value is statistically significant

Table 8: Comparison of flow velocity of vertebral artery of subjects before and after treatment by Doppler findings.

\begin{tabular}{|c|c|c|c|c|c|c|c|}
\hline \multirow{2}{*}{$\begin{array}{c}\text { FLOW } \\
\text { VELOCITY }\end{array}$} & & \multicolumn{2}{|c|}{$\begin{array}{c}\text { SUBJECTS BEFORE } \\
\text { TREATMENT }\end{array}$} & \multicolumn{2}{|c|}{$\begin{array}{c}\text { SUBJECTS AFTER } \\
\text { TREATM ENT }\end{array}$} & \multicolumn{2}{|c|}{} \\
\cline { 2 - 8 } & MEAN & SD & MEAN & SD & T-VALUE & P-VALUE \\
\hline $\begin{array}{c}\text { RIGHT } \\
\text { VERTEBRAL } \\
\text { ARTERY }\end{array}$ & PSV & 30.5 & 10 & 35.3 & 11 & 1.02 & $0.32 ; N S$ \\
\cline { 2 - 9 } & EDV & 9.14 & 1.25 & 11.37 & 3.02 & 2.15 & $0.04 ; 5$ \\
\hline $\begin{array}{c}\text { LEFT } \\
\text { VERTEBRAL } \\
\text { ARTERY }\end{array}$ & PSV & 28.1 & 14.4 & 40.1 & 8.1 & 2.29 & $0.03 ; 5$ \\
\cline { 2 - 9 } & EDV & 4.01 & 4.38 & 10.21 & 3.54 & 3.48 & $0.002 ; 5$ \\
\hline
\end{tabular}


The mean value for flow velocity of vertebral artery right $\mathrm{cm} / \mathrm{sec}$ in subjects before treatment is $30.5 \pm 10.0 / 9.14 \pm 1.25$ is less than in subjects after treatment $35.3 \pm 11.0 / 11.37 \pm 3.02$ and " $\mathrm{P}$ " value of $\mathrm{cm}$ is statistically non-significant and in sec is significant. The mean value for flow velocity of vertebral artery right $\mathrm{cm} / \mathrm{sec}$ in subjects before treatment is $28.1 \pm 14.4 / 4.01 \pm$ 4.38 is less than in subjects after treatment is $40.1 \pm 8.1 / 10.21 \pm 3.54$ and the " $P$ " value is statistically significant.

Table 9: Comparison of Intima media thickness of internal carotid artery and vertebral artery of subjects before and after treatment.

\begin{tabular}{|c|c|c|c|c|c|c|}
\hline & \multicolumn{2}{|c|}{$\begin{array}{l}\text { SUBJECTS BEFORE } \\
\text { TREATM ENT }\end{array}$} & \multicolumn{2}{|c|}{$\begin{array}{l}\text { SUBJECTS AFTER } \\
\text { TREATMENT }\end{array}$} & \multirow[b]{2}{*}{ T-VALUE } & \multirow[b]{2}{*}{ P-VALUE } \\
\hline & MEAN & SD & $\overline{\text { MEAN }}$ & SD & & \\
\hline $\begin{array}{l}\text { RIGHT INTIMA } \\
\text { MEDIA } \\
\text { THICKNESS (mm) }\end{array}$ & 1.11 & 0.24244 & 0.58 & 0.2 & & $\varangle 0.001 ; 5$ \\
\hline $\begin{array}{c}\text { LEFT INTIM A } \\
\text { MEDIA } \\
\text { THICKNESS } \\
(\mathrm{mm})\end{array}$ & 1.22 & 0.39 & 0.79 & 0.25 & 2.93 & $0.008 ; 5$ \\
\hline
\end{tabular}

The mean value of Intima media thickness (right) of subjects before treatment is $1.11 \pm 0.24$ is higher than subjects after treatment $0.58 \pm 0.20$ and " $P$ " value is statistically significant. The mean value of Intima media thickness (left) of subjects before treatment is $1.22 \pm 0.39$ is higher than subjects after treatment $0.79 \pm 0.25$ and " $P$ " value is statistically significant.

\section{DISCUSSION}

Age related changes are most marked from 60 years onwards. But the changes start from 38-40 years. So, it is observed in the present study that age and BMI values are statistically significant. Martin A. James et.al, [8] studied the ageing changes in an age group (older than 60 years) of subjects based on the widening of pulse pressure. In most of the studies the mean of 60 years group is selected. There is not much difference in the resting heart rate (Table -2) the individual variations indicate an increase in heart rate in more than $50 \%$ of subjects but, the values are not statistically significant. In table 2 mean values of systolic blood pressure and diastolic blood pressures are compared with statistical analysis. There is rise in systolic blood pressure $14+19.8$ and diastolic blood pressure $94.0 \pm 5.16$. So, the pulse pressure is widened in subjects.
These values are similar to Martin A. James et al. The main changes in big arteries are stiffness of elastic tissue, with much thicker and less flexible walls. This causes the increase force of ventricular contraction and systolic blood pressure. In the periphery the connective tissue decreases from skin and subcutaneous with decrease in tissue pressure and peripheral resistance. This may be the cause for fall in diastolic blood pressure and widening of pulse pressure indicates compliance of vascular system [9-10]. Ageing is associated with loss of compliance in the aorta and the principal arterial conduits. This loss of compliance is a powerful determinant of cardiovascular risk $[9,10]$. The structural changes in the large arteries of older individuals responsible for loss of compliance were felt to be largely irreversible. Recent evidence suggests a role for circulating nitric oxide (NO) in regulating large artery compliance. Several drug doses have been show to alter large vessel compliance [10]. These include calcium channel blockers, ACE inhibitors oral nitrates, and the potassium channel opening agent Nicorandil. The increasing recognition that large vessel stiffness plays a central path physiological role in hypertension in older individuals may help to guide clinicians in treating specific sub groups of folder hypertensive where evidence supporting one individual drug dose over another is absent $[3,10]$. The same changes may also be due to increase in serum lipid levels for this serum lipid profile is done in two groups and compared statistics. A Significant increase in serum cholesterol, triglycerides, and high density lipoproteins was observed in all subjects. This indicates the risk factor atherosclerosis in ageing for heart attacks and cerebral strokes $[3,4,10]$. Dynamic measurement of wall elasticity and viscosity were made which indicated a high viscosity in the femoral arteries. This was attributed in their high content of muscle. The young group showed at any given pressure, increasing wall stiffness towards the periphery in old arteries an opposite trend was found. When dimensional changes (radius and wall thickness) in the old group were considered it was apparent that at all sites the arterial wall tissue become weaker with age $[1,10]$.

New research initiatives should be taken up to 
including understanding of possible basic disease mechanisms and evidence for supporting the accurate diagnosis and treatment of age related diseases. The limitations of present study are its small sample size. We could not perform extensive urodynamic study due to technical constraints and unwillingness of our participants. Finally we drawn the report from our study, my reports were strongly supporting previous reports, and suggesting that the aged people have to do their Changes can be identified during regular routine medical checkups and the changes can be minimized by prescribing suitable diet, rest, minimal exercises.

\section{CONCLUSION}

The present study is undertaken to evaluate the cardiovascular changes in ageing in men and compared with the normal men. All the ageing men have the complaint of hypertension but in the normal men it is absent. The heart rate of the subjects and controls is found to be non-significant. The SBP and DBP of the subjects is found to be greater in ageing when compared with normal men due to changes in big arteries include stiffness of elastic tissue with much thicker and less flexible walls. This causes the increase force of ventricular contraction and SBP. The increase in large vessel stiffness plays a central patho physiological role in hypertension in older individuals. The lipid profile of the subjects is greater than the controls due to increase in plasma or serum lipid levels. This indicates the risk factor atherosclerosis in ageing. This is one of the predisposing factors for heart attacks and cerebral strokes. Changes can be identified during regular routine medical checkups and the changes can be minimized by prescribing suitable diet, rest, minimal exercises.

\section{REFERENCES}

[1]. Thomas H. Marwick, Thierry C. Gillebert, Gerard Aurigemma, Julio Chirinos, Genevieve Derumeaux, M aurizio Galderisi, John Gottdiener, BrianHaluska, Elizabeth Ofili, Patrick Segers, Roxy Senior, Robyn J. Tapp, and Jose L. Zamorano. Recommendations ontheuseofechocardiography in adult hypertension: a report fromthe European AssociationofCardiovascular Imaging(EACVI) and the American Society of Echocardiography (ASE). European Heart Journal - Cardiovascular Imaging (2015) 16, 577-605.

[2]. RobertN. Foley,patricks.parfrey,clinicl and echocardiographic disease in patients Cardiolnter1995,Jan 47(1):186-192.

[3]. Braunwald's heart disease. A text book of cardiovascular medicine. Indian edition, VIIedition, part IX, chapter 22:Page 1926

[4]. Sarada Subramanyam, Madavan Kutty, Singh H.D text book of Human Physiology-2006.

[5]. Jaek. OH, James B. Seward, Tamil Tajka A; The echo manual III edition, 2007, chap-2:7, 22, 23.

[6]. Celermajer D.S, K.E Sorenson, V.M Gooch, D.J. Spiegel halter,O.L Miller, I.D. Sullivan, J.k Lolyd and J.E. Dean field 1992. Non invasive detection of endothelial dysfunction in children and adults at risk of atherosclerosis. Lancet, 340:1111-1115.

[7]. Bijlani R.L, understanding medical physiology Chapter 3.10, page 46 and 169.

[8]. Blacher J, Asmar R.Djane S, London GM, Safar ME.Aortic pulse wave velocity as a marker of cardiovascular risk in hypertensive patients. Hypertension.1999; 33:1111-1117.

[9]. Blomstrand P, Konstando, Broquist M, Dahlstromu, Wrame B. Assessment of left ventricular diastolic function from mitral annulus motion, a comparison with pulsed Doppler measurements in patients with heart failure. Clinical physiology. 1996 sep; 16(5) 483-493.

[10]. Learoyd BM , Taylor M G. Alterations with age in the viscoelastic properties of human arterial walls. Cir Res. 1966;18:278-292.

\section{How to cite this article:}

M.V.Sailaja, V.S.Bhagyalakshmi, Vijitha. Identification of Cardiovascular Related Changes by Regular Routine Medical Checkups in Aged People. Int J Intg M ed Sci 2016;3(9):412-418. DOl: 10.16965/ijims.2016.149 